\title{
MEETING POTENTIAL PARENTS-IN-LAW AND INTRODUCING A PARTNER TO OWN PARENTS: PROSPECTIVE AND RETROSPECTIVE STUDIES
}

\author{
Paweł Ciesielski and Kamil Janowicz
}

Faculty of Psychology and Cognitive Science, Adam Mickiewicz University

\begin{abstract}
Parents-in-law are an important part of adult relationships. Contact with them may affect satisfaction and marital success of a married couple. Previous research shows that amount of contact with in-laws, support given by them and conflicts with them have a significant impact on the life of a couple. Little research has explored relationships of parents and parents-in-law with a couple before marriage. Even less is known about the beginnings of these relationships. This research consists of two studies which explored the vision and memories of the first meetings of potential in-laws and parents as a couple. Study $1\left(N_{l}=34\right.$, age $M=23.40, S D=2.32$, Woman $\left.=64.70 \% N_{l}\right)$ asked the participants how they imagined those events, while evaluating stress accompanying them. The participants reported predictions of feeling stressed by both events, but also of excitement, having no expectations, being ashamed by their own parents or being trustful in parents' behavior. Stress assessments of both events are inconclusive in establishing whether one of them is more stressful than the other. In Study $2\left(N_{2}=8\right.$, age $M=23.50, S D=2.67$, Woman $\left.=62.50 \% N_{2}\right)$ a sample of young adults was interviewed about their memories concerning situations of meeting their in-laws and introducing their partner to their own parents. The respondents recalled 37 features, of which experiencing stress and fear in both situations was common. All reflected on the way that the meeting happened and all but one described how they had prepared for it.
\end{abstract}

Keywords: in-laws; family psychology; stress; in-depth interviews; qualitive studies.

Pawel Ciesielski, https://orcid.org/0000-0002-2022-2706; Kamil JanOwiCZ, https:// orcid.org/0000-0002-6193-5331. Proofreading of this article was funded by the Faculty of Psychology and Cognitive Science of Adam Mickiewicz University. Correspondence concerning this article can be addressed to Pawee CiesIelski, Uniwersytet im. Adama Mickiewicza w Poznaniu, Wydział Psychologii i Kognitywistyki, ul. Szamarzewskiego 89 AB, 60-568 Poznań, Poland; e-mail: pawcie@st.amu.edu.pl.

Handling editor: MARIA KAźMIERCZAK, University of Gdansk.

Received 16 Jan. 2021. Received in revised form 12 April 2021. Accepted 13 April 2021. Published online 12 July 2021. 
Involvement in romantic relationships is ubiquitous in young adults (Bancroft, 2011). Some of these relationships may evolve into a marriage or non-formalized long-lasting relationship. According to the periodization of the family life cycle proposed by Halley (1973, as cited in Ostoja-Zawadzka, 1999), dating is the first phase of the cycle of family life. For most partners it is also the moment of meeting potential parents-in-law and introducing a partner to their own parents. Strengthening the relationship may lead to more frequent meetings of partners and their parents - two families become a new, bigger family. Unresolved problems in the family of origin are a possible source of difficulties at this stage of developing a romantic relationship (Kołbik, 1999a; Ostoja-Zawadzka, 1999). While this first meeting with potential parents-in-law and introducing a partner to one's own parents seems to be an important event, there is a lack of studies exploring experiences related to these situations in young adults.

This research, adopting a qualitative approach and consisting of two studies, aims to bridge this gap by exploring anticipations and memories related to meeting potential parents-in-law and introducing a partner to one's own parents. Data was gathered by means of a web survey and in-depth interviews.

\section{Conceptual Framework}

Early adulthood is a developmental stage in which intimate relationships take priority (Erikson, 2004; Havighurst, 1981; Levinson, 1988). It is a period of life when social pressure pushes adults to bind in pairs, and biological development allows people to fully embrace all aspects of being a couple. In Poland, the median age for marrying for the first time is 27.6 years old for women and 29.7 years old for men (Rozkrut, 2018).

As intimate relationships progress, partners spend more time together and, therefore, undertake more activities as a couple rather than individually, which also includes contacting their families. Even before marriage, parents and parents-in-law play a vital role in a budding relationship. This role increases when young people's relationships start to be more serious (Ostoja-Zawadzka, 1999). In the last decades, there has been an increasing interest in investigating relationships between young couples and their parents and parents-in-law, but still, there is not much research on that topic. Although most of it has been conducted in the last twenty years, there are some older ones. The findings of older and novel studies are usually consistent, so we decided to refer to the recent literature. However, few issues explored by former researchers have not been investigated in the last years-in such cases, we mentioned the older studies. 
Moving on to the findings from studies on relationships between young couples and their parents and parents-in-law, it is common that modern parents still have an image of an ideal partner that is partially different than their children's (Apostolou, 2008; Perilloux et al., 2011). Accordingly, both partners and parents may be worried about introducing each other due to perceived discrepancies between their own expectations toward the partners that they will meet and the expectations of the other side. It may also be stressful for the one who is being introduced because of the fear that they will not meet these expectations.

Parents' preferences toward their children's partners have real-life consequences on the relationships of young adults. The idea that good relations with parents and in-laws means a better quality of marriage for the young adults and their marital success has been well researched (e.g., Bradford et al., 2019; Serewicz et al., 2008). Some research suggests that more important than relations with in-laws is their disclosure about the family's operating instructions (Serewicz et al., 2008), which helps the newcomer feel comfortable around their new family. Bradford et al. (2019) proved that parents' approval of a young adult couple's relationship influenced the quality of their marriage, as perceived by the couple. Parental support also correlated with marital satisfaction (Blair \& Holmberg, 2008; Rodrigues et al., 2017) and both physical and mental health (Blair \& Holmberg, 2008).

As described above, relations with parents and in-laws are important for a young couple's marriage to function well. Even though pop culture states that relations with in-laws (especially mothers-in-law) are difficult, the research proves otherwise (Fowler \& Rittenour, 2017). People asked about the closeness to their parents-in-law state that they are amongst their close relations - both mother- and father-in-law (Santos \& Levitt, 2007). This declaration, however, does not always translate into behaviors, such as confiding in them (Lind Seal et al., 2016). Despite this, most people report having good relations with their in-laws (Prentice, 2008). It is not certain whether these relations are constant throughout their marriage. Some research states that people's relationships with their in-laws are better before the wedding and worsen afterwards (Turner et al., 2006) while others state that good relations before getting married facilitated better relations afterwards (Fingerman et al., 2012). Considering the research mentioned above, concern about a good atmosphere during meetings and mutual confidence in this relationship from the first introduction seems crucial for both partners and their parents.

Findings from studies on mutual relations between young couples, their parents, and their parents-in-law indicate that favor and support are bilaterally given in various stages of their married life (Chong et al., 2017; Lee et al., 2020; Reczek et al., 2010). However, relationships with in-laws are, in many aspects, similar to any other ones. Therefore, it is not possible to avoid all conflicts-although it is 
much less often than pop culture would suggest (Fowler \& Rittenour, 2017). Conflicts most likely become more serious when adult children did not fully separate from their parents (Silverstein, 1992). It is important to mention that conflicts are more common with in-laws than with biological kin (Ayers et al., 2020). Also, the intensity of conflict is not constant in time. Both conflict with in-laws and the inlaws' support of the couple are mostly present right after marriage, and both begin to fade over time (Fowler \& Rittenour, 2017). Reasons for conflict with in-laws are very diverse - with the most common motives concerning loyalty issues, such as in-laws feeling that they receive less attention than parents (Horsley, 1997), and issues related to material resources (Ayers et al., 2020).

In summary, there is extensive research on relations with in-laws, their approval, and sources of conflict, but there is very little data about the situation of meeting parents-in-law for the first time early in relationships. Accordingly, this research aims to explore the experiences of young people who are in the situation of meeting potential parents-in-law and introducing their partner to their own parents. Study 1 investigated young adults' anticipations about these situations, while Study 2 investigated this topic from a retrospective perspective.

\section{Research Questions and Hypotheses}

The studies that will be presented in this paper are exploratory in nature, and, therefore, there were no initial hypotheses. Study 1 aimed to explore 1) if the participants envisioned situations where they meet potential parents-in-law and introduce their partner to their own parents as being stressful and 2) which topics the participants recalled when envisioning these situations. Study 2 had more questions and explored situations that the participants already experienced regarding 1) stress, 2) feelings, fears, and hopes about the meetings, 3) relations with potential in-laws and their relationship with their partner in the context of these two situations, and 4) the circumstances of these situations. 


\section{STUDY 1}

\section{Method}

\section{Participants}

The criteria for Study 1 participants were: 1) ages between 20-28 years, 2) being in a heterosexual relationship, 3) have not yet been introduced to potential parentsin-law, 4) have not yet introduced their partner to their own parents. A group of 34 people ( $65 \%$ of female) meeting the inclusion criteria were recruited to participate in the study through Facebook. The ages of the participants ranged from 20 to 28 years $(M=23.40, S D=2.32)$. A majority of them $(82 \%)$ lived in a city (above 100,000 inhabitants). All were middle-school graduates, with 58\% at college, and $26 \%$ college graduates.

\section{Measures}

The internet survey consisted of three parts: 1) a sociometric questionnaire, 2) two open-ended questions, and 3) a modified Holmes and Rahe list of stressful events. In the sociometric survey, the participants were asked questions about their age, the status of their family, their places of origin and residences.

Vision of meeting potential parents-in-law and vision of introducing partner to their own parents. The open-ended question was as follows:

Please imagine a situation, in which you get to meet your partner's parents. Take a moment to do this. Think about what you are feeling. How do you think it will go? Do you have any hopes or fears concerning this event? How strong are they? Please describe this vision as broadly as possible while answering the above questions. Write as much as you feel is appropriate.

The second question was analogous, but it focused on the situation of introducing one's partner to their own parents. These answers were assessed by trained coders (Creswell, 2013), that is, psychology students in their final year who had completed a basic course in psychological diagnosis. The data was prepared for analysis in the following steps: 1) all coders analyzed all of the answers and prepared a list of categories of events, thoughts, emotions, etc. that were mentioned in their answers; 2) these lists were discussed and unified by all coders and the first author, including establishing indicators for each category; 3) all coders rated all of the answers in relation to the categories and indicators that were developed in the second 
step - they assessed whether people referred to each category or not in their answers; 4) in line with Lawshe's (1975, as cited in Hornowska, 2001) recommendations that, in the case of three raters, the content validity ratio (CVR) should be .99-according to this, each category has to be assessed as "present" in the answer by all coders for it to be included into the analysis; 5) the levels of agreement between coders have been established - it was high for both answers about meeting with potential parents-in-law (Kendall's $W=.797$ ) and introducing a partner to one's own parents (Kendall's $W=.819$ ).

Stress evaluation. The last part of the survey was a modified Holmes and Rahe list of stressful events (Sobolewski et al., 1999). The participants were asked to evaluate how events that were listed were stressful for them (on a scale from 1 to 10). There were nine different events in total, from which seven were inspired from or taken from the original list (death of a close relative, change of place of residence, serious sickness or accident with damage of the body, conflict in family, being mugged, robbed, or stolen from, beginning or ending of education, and holidays spent with family), and two were added by the researchers: meeting potential in-laws for the first time and introducing a partner to one's own parents for the first time.

\section{Results}

In this section, the results of Study 1 will be presented. The participants mentioned 17 different aspects about the situation of meeting potential parents-in-law. The most common ones were "feeling stressed" $(62 \%)$, "feeling highly stressed" (21\%), "having no expectations" (12\%), and "feeling excited" (12\%). All of these feelings are listed in Table 1.

The sample size does not allow statistical tests that check for gender differences. Features that were mentioned by only one person were labeled as "other." Among them, there were categories such as "feeling insecure in this situation," "fear of meeting one of the potential parents-in-law," and "experiencing fear."

In terms of the situation of introducing one's partner to one's own parents, participants mentioned 18 different features. The most common one was similar to the situation of meeting potential parents-in-law: "feeling stressed" (53\%). Other features that were also worth mentioning were "feeling ashamed by own parents" $(9 \%)$ and "being trustful in parents' proper behavior" (9\%). These features are listed in Table 2. Answers to this question were shorter and more diverse (the word count was $M=12.90, S D=18.00$, contrasted with $M=16.30, S D=16.60$ for answers related to the situation of meeting potential parents-in-law). However, this difference is not statistically significant $(t=0.717, p=0.476)$. Features that were mentioned 
by only one person were labeled as "other." Among them, there were motives, such as "experiencing fear," "awkwardness," and "importance of relations with own parents." In comparison, the respondents mentioned that they felt stressed more often in the situation of meeting potential parents-in-law. However, the difference was not statistically significant ( $M=62 \%$ vs $\left.M=47 \%, \chi^{2}=1.48, p=.22\right)$.

Table 1

Aspects of Meeting Potential Parents-In-Law

\begin{tabular}{|c|c|c|c|c|}
\hline $\begin{array}{l}\text { Reasons and feelings } \\
\text { mentioned by respondents }\end{array}$ & Sample answers & $\begin{array}{l}\text { Total } \\
(\%)\end{array}$ & $\begin{array}{c}\text { Men } \\
(\%)\end{array}$ & $\begin{array}{l}\text { Women } \\
(\%)\end{array}$ \\
\hline Feeling stressed & $\begin{array}{l}\text { "I would certainly feel stressed } \\
\text { and nervous" }\end{array}$ & 62 & 33 & 77 \\
\hline Feeling highly stressed & "It will be an enormous stress" & 21 & 17 & 23 \\
\hline Having no expectations & "A normal meeting" & 12 & 25 & 5 \\
\hline Feeling exited & "I can't wait to meet them" & 12 & 17 & 9 \\
\hline Feeling mildly stressed & "I expect I will be slightly stressed" & 8 & 25 & 0 \\
\hline $\begin{array}{l}\text { Wanting to make good } \\
\text { first impression }\end{array}$ & $\begin{array}{l}\text { "I want to show myself } \\
\text { in the best light" }\end{array}$ & 8 & 8 & 9 \\
\hline $\begin{array}{l}\text { Fear of being judged } \\
\text { by potential parents-in-law }\end{array}$ & $\begin{array}{l}\text { "I'm worried that I will be rejected } \\
\text { by them from the start" }\end{array}$ & 8 & 8 & 9 \\
\hline $\begin{array}{l}\text { Being questioned by potential } \\
\text { parents-in-law }\end{array}$ & $\begin{array}{l}\text { "They will ask me a series of } \\
\text { questions to know more about me" }\end{array}$ & 6 & 8 & 5 \\
\hline Official situation & $\begin{array}{l}\text { "I will probably meet them during } \\
\text { some fancy diner at their home" }\end{array}$ & 6 & 0 & 9 \\
\hline Awkwardness & $\begin{array}{l}\text { "The first meeting will be rather } \\
\text { awkward" }\end{array}$ & 6 & 0 & 9 \\
\hline Other & & 21 & 25 & 23 \\
\hline
\end{tabular}

The participants also evaluated stress that occurs in different events. The most stressful events for them were deaths of a close relative and serious sicknesses $(M d n=10.00)$, conflicts in their family $(M d n=10.00)$, and being mugged, robbed, or having something stolen from them $(M d n=8.00)$. Introducing their partner to their own parents was ranked as moderately stressful $(M d n=6.50)$, as was meeting potential parents-in-law $(M d n=5.50)$. The differences in stress levels between these two events was statistically significant $(W=115 ; p<.05)$. Changing residence and beginning or finishing education were both less stressful than the events that were previously mentioned $(M d n=5.00)$, and holidays spent with family were rated as being the least stressful events $(M d n=3.00)$. 
Table 2

Aspects of Introducing Partner to Own Parents

\begin{tabular}{|c|c|c|c|c|}
\hline $\begin{array}{l}\text { Reasons and feelings } \\
\text { mentioned by respondents }\end{array}$ & Sample answers & $\begin{array}{l}\text { Total } \\
(\%)\end{array}$ & $\begin{array}{l}\text { Men } \\
(\%)\end{array}$ & $\begin{array}{l}\text { Women } \\
(\%)\end{array}$ \\
\hline Feeling stressed & $\begin{array}{l}\text { "I will be stressed with how } \\
\text { the conversation goes" }\end{array}$ & 47 & 33 & 54 \\
\hline Feeling ashamed by own parents & "I will be ashamed" & 9 & 17 & 5 \\
\hline $\begin{array}{l}\text { Being trustful in parents proper } \\
\text { behavior }\end{array}$ & $\begin{array}{l}\text { "My parents are cool } \\
\text { so everything will be alright" }\end{array}$ & 9 & 17 & 5 \\
\hline $\begin{array}{l}\text { Participant thinks this situation will } \\
\text { not happen }\end{array}$ & $\begin{array}{l}\text { "I think it will not come } \\
\text { to this situation" }\end{array}$ & 6 & 8 & 5 \\
\hline Lack of vision & "Just a normal meeting" & 6 & 8 & 5 \\
\hline Feeling highly stressed & $\begin{array}{l}\text { "It will be very stressful, but } \\
\text { I think they will like him" }\end{array}$ & 6 & 8 & 5 \\
\hline Feeling mildly stressed & $\begin{array}{l}\text { "It will be a bit stressful } \\
\text { for me as well" }\end{array}$ & 6 & 17 & 0 \\
\hline $\begin{array}{l}\text { Uncertainty of one of the parents } \\
\text { appropriate behavior }\end{array}$ & $\begin{array}{l}\text { "I will be stressed with my father } \\
\text { who likes to joke and I hope he } \\
\text { will not embarrass me" }\end{array}$ & 6 & 0 & 9 \\
\hline Other & & 29 & 25 & 32 \\
\hline
\end{tabular}

STUDY 2

\section{Method}

\section{Participants}

Participants were invited to take part in Study 2 by a group of volunteers (members of a Students' Science Club of Family Science) who advertised the research on Facebook pages and among their friends and colleagues. The volunteers did not have any contact with people they invited during the study. The participants filled out a short contact form online and later were contacted by the interviewer who confirmed that the inclusion criteria were met and scheduled date of the interview. Four participants were excluded at this stage due to their resignation. The criteria for the groups were 1) ages between 20-28 years, 2) being in a heterosexual relationship, 3) having been introduced to potential parents-in-law in the last six months, 4) having introduced their partner to their own parents in the last six months. Eight people (five women and three men), aged from 21 to 28 years old $(M=23.50$, 
$S D=2.67)$, volunteered to participate in this study. More detailed information about the participants of Study 2 is presented in Table 3.

Table 3

Study 2 Participants

\begin{tabular}{lccccc}
\hline \multicolumn{1}{c}{ Name } & Gender & Age & Education & Residence & $\begin{array}{c}\text { Length of relation- } \\
\text { ship (in months) }\end{array}$ \\
\hline Alicja & Female & 21 & At college & City & 12 \\
Marta & Female & 24 & At college & City & 5 \\
Piotr & Male & 23 & At college & City & 8 \\
Zuzanna & Female & 22 & At college & City & 5 \\
Grzegorz & Male & 28 & College graduate & City & 9 \\
Joanna & Female & 27 & At college & Village & 5 \\
Julia & Female & 22 & At college & Village & 9 \\
Łukasz & Male & 21 & At college & City & 6 \\
\hline
\end{tabular}

\section{Measures}

In the second part of this research, a semi-structured, in-depth interview was used. Questions for this interview were inspired by the data that was obtained in Study 1 . The interviewers were psychology students in their final year who had completed basic courses in psychology assessment, including conducting diagnostic interviews. They were also trained in research procedures by the first author to get them accustomed to the procedures. Due to the coronavirus outbreak, all interviews were held online using Skype. The use of microphone and camera by both sides was mandatory. Before the interview, a short survey about the participants' ages, duration of their relationships, education, places of residence, places of work, and the status of their families were conducted. After this preliminary stage, the respondents were asked to describe situations in which they met potential parents-in-law. If the answer was not detailed enough, follow-up questions were asked. The second part of the interview focused on the situation in which the participant introduced their partner to their own parents. As before, follow-up questions were prepared to give the answers more depth. The audio for all of the interviews was recorded (consent to that was a prerequisite) and transcribed. The procedures for training coders and analyzing data from interviews was the same as in Study 1. The levels of agreement between coders have been established as being high for both memories about meeting with potential parents-in-law (Kendall's $W=.868$ ) and introducing a partner to one's own parents (Kendall's $W=.832$ ). 


\section{Results}

This part of our paper will report the results of the interviews that were conducted in Study 2. Competent judges pointed out more than 200 categories that could be used when describing the interviews. Thirty-seven of them were coded as being present by all three of the judges in at least one interview. These 37 categories were aggregated into six main categories: 1) fears, hopes, and expectations of the meetings, 2) preparations before the meetings, 3) circumstances of the meetings, 4) stress related to the meetings, 5) evaluation of the meeting after it happened, and 6) meetings and relations with one's partner, parents, and potential parents-in-law.

The first of these categories involved fears, hopes, and expectations concerning the meetings. This was a very diverse group of categories, especially when the participants' fears were analyzed. Half of them experienced stress in the situation of meeting potential parents-in-law (MPIW) or due to the situation of introducing their partner to their own parents (IPP). For example, Marta described her fear of presenting herself badly like this:

[MPIW] "It was already $9 \mathrm{pm}$, so I was stressed because it was already late, and I didn't want it to be seen badly by his parents."

Few people mentioned the fear of feeling awkward during the meeting as a reason for being uncomfortable. Grzegorz described it like this:

[MPIW] "No, I wasn't afraid, I just didn't want to... I didn't want this meeting to be awkward or too long-You could say that I was afraid of this awkwardness."

Alicja, however, had more concerns about the situation of introducing her partner to her parents. She was afraid of being embarrassed by her own parents:

[IPP] "Yes, I was afraid that the whole family would judge him, because they are simple people, and they judge people by their looks... and I was afraid that they would do that. And I would be completely ashamed of them."

However, it is worth mentioning that not all of the participants stated that they feared anything about these events. Zuzanna, for example, feared neither of these situations: 
[MPIW] "But—no, I didn't have any fears or anything like that. The meeting was... let's say, natural. People meet with each other and talk just like normal."

[IPP] Did you fear this moment in any way?

"No, I don't think so. I had this... I knew that both he and my parents are talkative so... it would be all right. It would work out fine."

Apart from experiencing fears, some of the respondents stated that they wanted to have good relations with potential in-laws, and some stated that they wanted their partner to have good relations with their own parents. Julie and Marta described these feelings like this:

Julia [MPIW]: "I also just wanted to have good relations with his parents; I cared about it because I knew that he is in close contact with them."

Marta [IPP]: "I knew that my boyfriend would present himself well, and I knew that my parents would like him, so I wasn't worried about it... Yes, it was important to me-also because I wanted for them to be in good relations with each other."

The second theme that was revealed in the interviews was related to the preparations before the meeting. Almost all of the participants prepared themselves in some way before meeting their potential parents-in-law. Piotr, for example, involuntarily gathered some information by talking with his partner, and, thanks to that, he felt prepared for the meeting:

[MPIW] You mentioned that your girlfriend told you a lot about her parents...

"Yes, it helped because it was like she had told me-as she described them to me. Like that, her mom is talkative...

Were there many talks like this?

"No, it was simply in our talks... and she described her parents to me, how it is with them. I also asked some questions out of curiosity." 
Joanna also obtained some information about topics to talk about during the meeting:

[MPIW] "But I tried to talk with them about topics that they are interested in, but they didn't seem to care."

Julia, who also prepared, bought a gift for her potential in-laws:

[MPIW] "And I bought—God, what did I buy? This kind of garden in a glass or something like that, so there was that."

Most of the participants stated that they did not prepare their partner or parents for their introduction. Zuzanna explained it along these lines:

[IPP] Some people prepare their partner before meeting their parents. How was it in your case?

"No there was no such thing. Really, as I said, my boyfriend came to me, so... We didn't think of it like he was coming to meet my parents."

The third theme described the circumstances of the meetings. Most of the participants described their MPIW as informal, and some described those meetings in the same way as their IPP. Łukasz said this about his MPIW:

Was it a formal situation?

"No, absolutely not. This casual situation helped in meeting people."

Grzegorz, however, experienced his IPP as a formal event:

"It was around Christmas - on a first or second day of holiday.

We came for tea, and it was more official and somewhat funny."

In some cases, meeting potential in-laws and introducing their partner was not the main purpose of those events. For example, Joanna described it thus:

[IPP] "My god, if it wasn't for the quarantine, he wouldn't meet them... There was no other choice. I had birthday then, and he camewhich was cool though I was trying to avoid this situation." 
The next category involved the participants' experiences with stress. Many of them felt stressed by their MPIWs. Lucas described this in the first part of his interview:

"I mean, it was - concerning emotions, it was quite stressful— like any other first time. But there were no bigger problems."

For Grzegorz, however, stress was difficult to distinguish from other emotions, and, finally, he qualified it as a mild stress:

[MPIW] "Well, it's hard for me to call it stress - maybe something more like some awkwardness, a bit of awkwardness, and I think it was a little bit of stress."

The situation of IPP was not stressful for a majority of the participants. However, many of them saw that their partners were stressed. For example, Piotr recalled this event as follows:

"No, I mean, I know that she was stressed way more than me. She was stressed, while I-it was easy for me, while you could see that she was terribly stressed, right?"

The fifth category contained the participants' retrospective reflections on the events, such as if they liked the form of the meeting or how they felt about their potential in-laws. Half of the participants liked the way that their MPIW took place. Zuzanna stated:

[MPIW] "I'm satisfied with how it looked — that everything looked pretty natural and... that there was no embarrassment, that there was nothing to be changed."

However, some participants would have preferred that the meeting took place on a more neutral ground or that the potential in-laws were more communicative. Alicja described it like this:

[MPIW] "If I could change something? Hmm. I would maybe, most certainly change the place because being at their house was far more uncomfortable than if we would meet somewhere in town. So, I would change that." 
In their IPP, some of the participants also would have liked it to be slightly different. For example, Piotr wanted there to be less people during this event, while Joanne preferred the meeting to take place on a neutral ground (similarly to Alicja in her MPIW). Julie wanted her parents to behave differently. This is how she described it:

[IPP] "I could have warned my mother so that she would sit longer with us because she didn't from what I can remember. She tends to leave the table as soon as someone comes. I could have prepared her so she would sit longer with us."

Finally, even though the potential in-laws were often interested in the newcomers and showed it by asking them questions, for example, in only one of the interviews, the potential parents-in-law were seen as nice during the meeting. Łukasz summed it up briefly:

[MPIW] "They were very nice and kind. Very open. They were fine."

The last category focused on how the events were received from perspective of the participants' relationships with their partners and both their parents and potential in-laws. An important subcategory was the feeling of their parents approving of their partners and feeling approval from their potential parents-in-law. Alicja and Marta described it like this:

Alicja [MPIW] "I mean, I felt approval when I talked about my college - this is something that they approve - and that is to my advantage. And, also, I worked, and, when I had a stable job when I worked, then I also felt that they approved that."

Marta [IPP]: "They [parents] were very positive, smiled, they gladly talked with us, and asked some questions. They were very positive. Yes, he [boyfriend] definitely earned their approval."

Apart from feelings of approval, many of the participants thought that these events had a positive effect on their relationships with their partners. Eukasz said this when he was asked about his MPIW: 
How did this event change your relationship with your girlfriend? "Positively, because since there were no comments about me meeting her parents or the other way around, then it meant that it influenced us positively."

Half of the participants thought that the IPP had positive consequences on their relationships. Julia described it like this:

"You know, meeting each other's parents is a next step in a relationship... he [boyfriend] could better understand some of my problems, which result from my relations with my mother."

Apart from the categories that are presented above, there were many more that could not be included due to text limitations. The main categories in this study were recalled by most of the participants. In summary, although the respondents had various feelings, thoughts, and experiences about the situations of meeting potential parents-in-law and introducing one's partner to one's own parents, the following can be said: 1) they were both somehow stressful for the couple, 2) the partners usually tried to prepare (in various ways) for these situations, 3 ) the partners were thinking about the upcoming meetings before they happened, and 4) the partners usually made some kind of evaluation of the meeting - both in relation to how it went and how it might affect their relationship with their partner.

\section{DISCUSSION}

Relations with parents and parents-in-law are one of the most important parts of the lives of married adults. This research investigated the beginning of couples' relations with both their parents and parents-in-law. Both participants and their partners were received well most of the time, which bodes well for the perceived quality of their relationships (Bradford et al., 2019). In most cases, parents gave direct information to the participant that they liked their partner, which may be a good practice to ensure feelings of parental approval in a young adult.

In both studies, there are only few direct statements that the respondents do not care about relations with their future in-laws. On the other hand, only one out of the eight participants in Study 2 stated that they wanted to have good relations with their in-laws, and three of them wanted to make a good impression during their meeting. 
Hence it may be hypothesized that not all the participants cared about relations with their in-laws. On the other hand, it is possible that the participants were not completely aware of the desire to have good relations with their potential parentsin-law, and they could not have expressed it directly. Stress, both experienced and anticipated, might be a manifestation of this wish, but it could also be related to different feelings and desires. However, there is not enough data to determine which of these explanations is more adequate. Further studies should investigate that issue. It is also possible that having no need for good relations with in-laws is a predictor of bad relations with them in the future. As indicated by the study conducted by Fingermann and colleagues (2012) good relations before getting married facilitate better relations afterward. Therefore, future studies should investigate the long-term consequences of the first impressions from the relations between partners and their parents on further emotional climates, support levels, and marital successes in these couples. It has to be taken into the account that these studies were conducted on Poles of late generations $\mathrm{Y}$ and early $\mathrm{Z}$ (depending on the classification used), and they may have different mentalities and consequences of it on marital success than what was shown in previous studies. Further research is needed to explore this subject.

If we assume that only some people care about relations with in-laws, it is interesting to see that so many of the participants described meeting them as being stressful. In both visions and memories of this event, stress was a common feature that was described in both meeting potential parents-in-law and introducing their partner to their own parents. One of the possible explanations for this comes from the concept of loyalty from systems psychology, which describes identifying with a group and its members trusting in them and being trustworthy, taking responsibility for them, and committing oneself to the group (Kołbik, 1999b). Both events that were studied in this research can be interpreted in the context of loyalty. Introducing one's partner to one's own parents means introducing a new person to a family group and taking responsibility for them. In the situation of meeting potential in-laws for the first time, a person is being invited to a new group.

These studies also provide puzzling results concerning the question of whether introducing a partner to one's own parents or meeting potential parents-in-law for the first time is more stressful. Study 1 provided conflicting data. An analysis of participants' answers suggests that meeting in-laws is the more stressful event (having more mentions of stress at all and of high levels of stress). However, quantitative data leads to the conclusion that introducing one's partner to one's own parents is the more stressful event. Further research is required to resolve these inconsistencies. 


\section{LIMITATIONS AND DIRECTIONS FOR FURTHER RESEARCH}

In this study due to the disproportion of gender (most of the participants were women) and small sample size, this sample should not be treated as a representation of the population. Also, the participants were all volunteers, which may cause bias in some of the results. Future researchers should focus on studying larger groups (especially men and people from rural areas) that would be representative of the population. It is also important to test hypotheses about the influence of family loyalty on experiencing situations of meeting potential parents-in-law and introducing one's partner to one's own parents. A different field that is worth exploring is experiencing these situations in non-heterosexual relationships (especially in cultures that can be described as homophobic). Longitudinal studies may bring us deeper insights into dynamic changes in relations between young couples, their parents, and potential parents-in-law. Investigating how potential problems in these relations affect future family life could have vital practical implications.

\section{CONCLUSION}

Relations between young couples and their parents are most certainly complicated. This research brought deeper insights into the topic, which have rarely been investigated in earlier empirical studies, and presented some details about the first experiences of how these relations are formed. Young people usually predicted that these situations would be stressful, and that was a dominant theme in their answers. Similarly, stress was one of the main categories that was present in the participants' recollections of meeting potential parents-in-law and introducing their partners to their own parents for the first time. Despite feeling a lot of stress and fear about these situations, most of the participants described these events as positive experiences, which contrasts with pop culture's narrative that conflict and troubled relationships with in-laws are inevitable. The findings of these studies, which are both quantitative and qualitative, encourage the development of further studies on the role of the wider family context in the dynamics of intimate relationships in their early stages. 


\section{CRediT Author Statement}

Pawel Ciesielski (70\%): conceptualization, methodology, formal analysis, investigation, data curation, writing (original draft), project administration, visualization, funding acquisition.

KAMIL JANOWICZ (30\%): conceptualization, methodology, formal analysis, writing (original draft), supervision.

\section{REFERENCES}

Apostolou, M. (2008). Parent-offspring conflict over mating: The case of beauty. Evolutionary Psychology, 6(2), 303-315. https://doi.org/10.1177/147470490800600207

Ayers, J., Krems, J., Hess, N., \& Aktipis, A. (2020). Mother-in-law daughter-in-law conflict: An evolutionary perspective, ethnographic review, and report of empirical data from the United States. PsyArXiv. https://doi.org/10.31234/osf.io/uvcp4

Bancroft, J. (2011). Seksualność człowieka (R. Śmietana, Trans.). Elsevier Urban \& Partner.

Blair, K. L., \& Holmberg, D. (2008). Perceived social network support and well-being in same-sex versus mixed-sex romantic relationships. Journal of Social and Personal Relationships, 25(5), 769-791. https://doi.org/10.1177/0265407508096695

Bradford, A. B., Drean, L., Sandberg, J. G., \& Johnson, L. N. (2020). They may disapprove, but I still love you: Attachment behaviors moderate the effect of social disapproval on marital relationship quality. Family Process, 59(4), 1-22. https://doi.org/10.1111/famp.12519

Chong, A., Gordon, A. E., \& Don, B. P. (2017). Emotional support from parents and in-laws: The roles of gender and contact. Sex Roles, 76(5-6), 369-379. https://doi.org/10.1007/s11199-016-0587-0

Creswell, J. (2013). Research design: Qualitative, quantitative, and mixed methods approaches (4th ed.). Sage.

Erikson, E. (2004). Tożsamość a cykl życia (M. Żywicki, Trans.). Zysk i S-ka.

Fingerman, K. L., Gilligan, M., Vander Drift, L., \& Pitzer, L. (2012). In-law relationships before and after marriage: Husbands, wives, and their mothers-in-law. Research in Human Development, 9(2), 106-125. https://doi.org/10.1080/15427609.2012.680843

Fowler, C., \& Rittenour, C. (2017). A life-span approach to children-in-law's perceptions of parent-in-law communication. Journal of Family Communication, 17(3), 254-272. https://doi.org/10.1080/15267431.2017.1281280

Halley, J. (1973). Uncommon Therapy. W. W. Norton.

Havighurst, R. J. (1981). Developmental tasks and education. Longman.

Hornowska, E. (2001). Testy psychologiczne: teoria i praktyka. Scholar.

Horsley, G. C. (1997). In-laws: Extended family therapy. American Journal of Family Therapy, 25(1), 18-27. https://doi.org/10.1080/01926189708251051

Kołbik, I. (1999a). Procesy emocjonalne w rodzinie [Emotional processes in the family]. In B. de Barbaro (Ed.), Wprowadzenie do systemowego rozumienia rodziny [Introduction to the systemic understanding of the family] (pp. 31-44). Wydawnictwo Naukowe Uniwersytetu Jagiellońskiego. 
Kołbik, I. (1999b). Lojalność rodzinna [Loyality in the family]. In B. de Barbaro (Ed.), Wprowadzenie do systemowego rozumienia rodziny [Introduction to the systemic understanding of the family] (pp. 78-84). Wydawnictwo Naukowe Uniwersytetu Jagiellońskiego.

Lawshe, C. H. (1975). A quantitative approach to content validity. Personnel Psychology, 28, 563-575.

Lee, J. E., Kim, K., Cichy, K. E., \& Fingerman, K. L. (2020). Middle-aged children's support for parentsin-law and marital satisfaction. Gerontology, 66(4), 340-350. https://doi.org/10.1159/000505589

Levinson, D. J. (1988). The seasons of a man's life. Alfred A. Knopf.

Lind Seal, K., Doherty, W. J., \& Harris, S. M. (2016). Confiding about problems in marriage and longterm committed relationships: A national study. Journal of Marital and Family Therapy, 42(3), 438-450. https://doi.org/10.1111/jmft.12134

Ostoja-Zawadzka, K. (1999). Cykl życia rodzinnego [The cycle of family life]. In B. de Barbaro (Ed.), Wprowadzenie do systemowego rozumienia rodziny [Introduction to the systemic understanding of the family] (pp. 18-30). Wydawnictwo Naukowe Uniwersytetu Jagiellońskiego.

Perilloux, C., Fleischman, D. S., \& Buss, D. M. (2011). Meet the parents: Parent-offspring convergence and divergence in mate preferences. Personality and Individual Differences, 50(2), 253-258. https://doi.org/10.1016/j.paid.2010.09.039

Prentice, C. M. (2008). The assimilation of in-laws: The impact of newcomers on the communication routines of families. Journal of Applied Communication Research, 36(1), 74-97. https://doi.org/10.1080/00909880701799311

Reczek, C., Liu, H., \& Umberson, D. (2010). Just the two of us? How parents influence adult children's marital quality. Journal of Marriage and Family, 72(5), 1205-1219. https://doi.org/10.1111/j.1741-3737.2010.00759.x

Rodrigues, D., Lopes, D., Monteiro, L., \& Prada, M. (2017). Perceived parent and friend support for romantic relationships in emerging adults. Personal Relationships, 24(1), 4-16. https://doi.org/10.1111/pere.12163

Rozkrut, D. (Ed.) (2018). Rocznik Statystyczny [Statistical Yearbook]. Główny Urząd Statystyczny.

Santos, J. D., \& Levitt, M. J. (2007). Intergenerational relations with in-laws in the context of the social convoy: Theoretical and practical implications. Journal of Social Issues, 63(4), 827-843. https:// doi.org/10.1111/j.1540-4560.2007.00539.x

Serewicz, M. C. M., Hosmer, R., Ballard, R. L., \& Griffin, R. A. (2008). Disclosure from in-laws and the quality of in-law and marital relationships. International Journal of Phytoremediation, 56(4), 427-444. https://doi.org/10.1080/01463370802453642

Silverstein, J. L. (1992). The problem with in-laws. Journal of Family Therapy, 14(4), 399-412. https:// doi.org/10.1046/j..1992.00469.x

Sobolewski, A., Strelau, J., \& Zawadzki, B. (1999). Kwestionariusz Zmian Życiowych (KZŻ): Polska adaptacja kwestionariusza “Recent Life Changes Questionnaire” (RLCQ) R. H. Rahe'a. Przeglad Psychologiczny, 42(3), 27-49.

Turner, M. J., Young, C. R., \& Black, K. I. (2006). Daughters-in-law and mothers-in-law seeking their place within the family: A qualitative study of differing viewpoints. Family Relations, 55(5), 588-600. https://doi.org/10.1111/j.1741-3729.2006.00428.x 